\title{
Online Research Portal
}

\author{
Ramil G. Lumauag \\ Associate Professor III \\ Iloilo Science and Technology Miagao Campus, Miagao, Iloilo \\ ramilglumauag@gmail.com
}

\begin{abstract}
A Web Portal is a website or service that offers a broad array of resources and online services, such as search engines, directories, news, e-mail, and online information. Portals have evolved to provide a customized gateway to Web information. This study aimed to develop an Online Research Portal. Specifically, it aimed to create an online repository of researches and articles, publish researches and articles online, manage web content, distribute content depending on the user privileges and access level, create a venue for collaboration with other research institutions, create linkages with other research institutions, access information while off-campus, and disseminate latest update on research. An Evolutionary Prototype Model was used to develop the system and a test case was used to test the functionality. The respondents of the study were the randomly selected 25 Faculty of ISAT U Miagao Campus as well as 5 IT Experts coming from different sectors, and the system was evaluated by the IT Experts and Faculty using ISO 9126 software quality characteristics such as functionality, reliability, usability, efficiency, maintainability, and portability. Mean and standard deviation were used as statistical tool for this study. The experts' evaluation of the system based on ISO 9126 criteria is effective and the faculty evaluation is very effective. The overall result of the evaluation is very effective, and the system meets the criteria for software quality characteristics; therefore, it is recommended to be implemented.
\end{abstract}

\section{Keywords}

Research Portal, Online Portal, Web Portal

\section{INTRODUCTION}

A Web Portal is a website or service that offers a broad array of resources and online services, such as search engines, directories, news, e-mail, and online information. Portals have evolved to provide a customized gateway to web information. University portals can be a means for establishing a long-term relationship with the institution. They not only make it easy to do business with the institution, but they allow for interaction and collaboration among students, faculty, staff, and graduates with similar needs and interests. Properly implemented, portals can be a strategic asset for the institution. In that sense, they do far more than a traditional Web site of static information ever could. (Richard N. Katz and Associates, 2006). Englert (2003) gives the following reasons to why universities are implementing portals. These are to: integrate/streamline information and services; improve service to students/ staff; offer personalized/customized/targeted service; improve administration efficiency; attract students. It enhances the university image/raise profile; engage/connect/build community; and offer distance/flexible learning.

Research is mandated in every university, and research publications are required especially for professorial rank. Research outputs should also be presented, published and disseminated in any form such as public forum, print media, as well as online media. The researcher as and IT Professor at The Iloilo Science and Technology University (ISAT U) Miagao Campus was motivated to develop this online research portal to help the university showcase its researches through online publications, and disseminate research outputs which can help the community and improve the society.

\section{Objectives of the Study}

This study aims to develop an Online Research Portal.

Specifically, it aims to:

1. create an online repository of researches and articles

2. publish researches and articles online

3. manage web content

4. distribute content depending on the user privileges and access level

5. create a venue for collaboration with other research institutions

6. create linkages with other research institutions

7. access information while off-campus

8. disseminate latest update on research

\section{Conceptual Framework}

Figure 1 shows the conceptual framework of the study illustrating the flow of the system. As shown in figure 1, the input will be the research abstracts, articles, latest updates, and the creation of user account information. These contents will be managed, and published online. Researches will be categorized based on its specific category. A mechanism will be 
developed to manage account privileges to ensure the security of the content. Once published, all research outputs, articles, and updates can be viewed online.

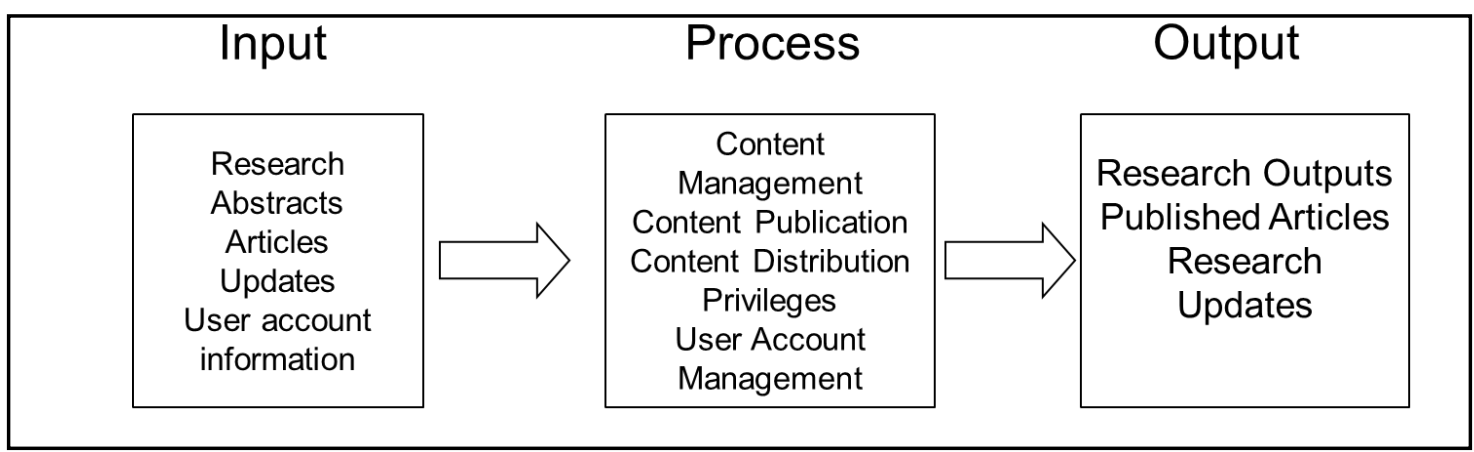

Fig 1: Conceptual Model

\section{RELATED WORKS}

\section{The Getty Research Portal}

The Getty Research Portal is an online search platform providing global access to digitized art history texts. Through this multilingual, multicultural union catalog, scholars can search and download complete digital copies of publications for the study of art, architecture, material culture, and related fields. The Portal is free to all users. The online portal can be found at http://portal.getty.edu/portal/landing

\section{Natural Sciences and Engineering Research Council of Canada Research Portal}

The Research Portal is intended for use only by individuals participating in the preparation of applications/nominations for funding from the Canada Research Chairs, the Research Support Fund, and other programs of the Natural Sciences and Engineering Research Council of Canada (NSERC) and the Social Sciences and Humanities Research Council of Canada (SSHRC), in the administration of awards, and in the merit review of applications. NSERC's Research Portal provides a single point of entry for all of our interactions with applicants, reviewers, committee members, institutions and partners. This is a secured portal intended for members only, it can be found at http://www.nserc-crsng.gc.ca/ResearchPortalPortailDeRecherche/Index_eng.asp

\section{Hongkong Polytechnic University Research Office Portal}

The research portal contains the latest update about the research office such as call for papers, latest announcements, and other research related information. It has also a secured member page where it allows member to login and download resources. It can be found at https://www40.polyu.edu.hk/rostudportal

\section{Socio Economic Research Portal for the Philippines}

Socio Economic Research Portal for the Philippines is an online knowledge repository of socioeconomic materials produced by the Philippine Institute for Development Studies (PIDS) and other government agencies, academic and research institutions, and development organizations comprising the SERP-P Network. It contains the latest news, publications and call for papers, it can be found at http://serp-p.pids.gov.ph/home/index.html

\section{University of the Philippines Los Baños Portal}

UPLB has a dedicated portal just for its research, development and extension activities. It features a bi-annual newsletter, a collection of video presentations, databases of experts, projects and technologies, a catalog of training programs offerings and analytical services, and a calendar of events. The UPLB RDE Portal is maintained by the Office of the ViceChancellor for Research and Extension. It can be found at http://uplb.edu.ph/index.php/research

\section{METHODOLOGY}

Figure 2 shows the Evolutionary Prototyping Model which will be used in the development of the system. Prototyping is most useful in development of systems having high level of user interactions such as online systems. Systems which need users to fill out forms or go through various screens before data is processed can use prototyping very effectively to give the exact look and feel even before the actual software is developed. 


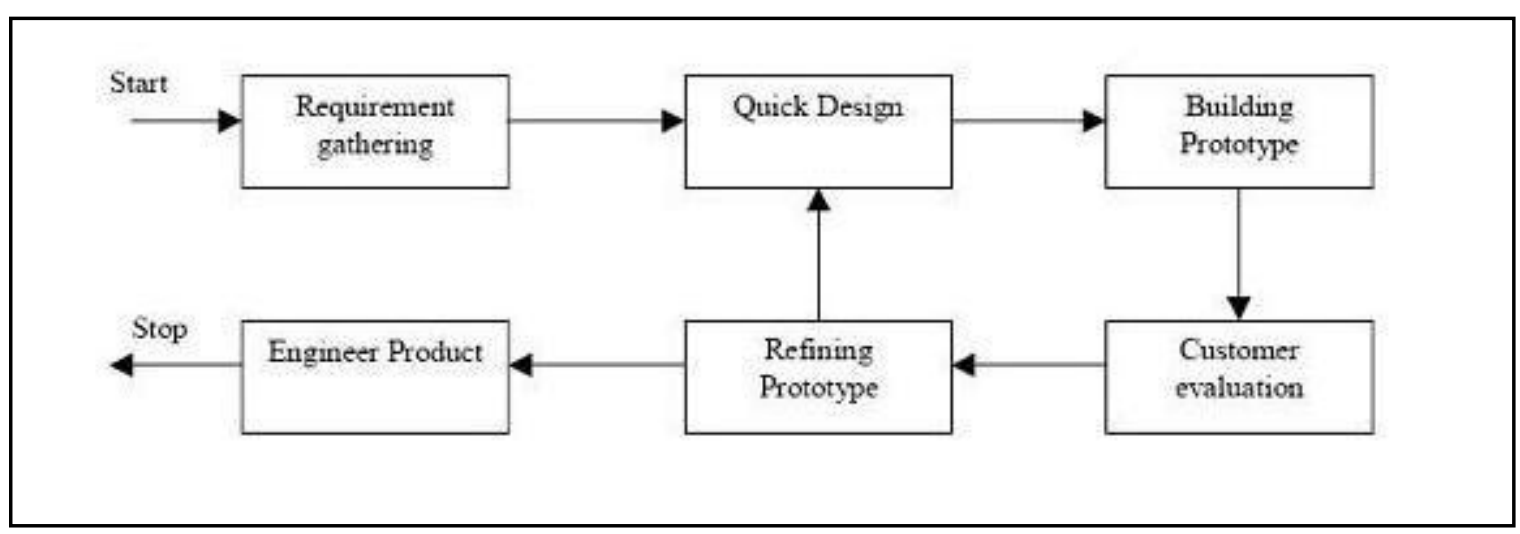

Fig 2: Evolutionary Prototyping Model

\section{Requirement Gathering}

This step involves understanding the very basics product requirements especially in terms of user interface. In this phase, data from the research office will be collected and identified.

\section{Quick Design}

This step involves designing the user interface, graphical design, as well as building the initial requirements of the system.

\section{Building Prototype}

This step involves building the model, in this phase the actual process is defined, its functionality and interfaces.

\section{Customer Evaluation}

In this step, the prototype developed is then presented to the users and the other important stakeholders in the project. The feedback is collected in an organized manner and used for further enhancements in the product under development.

\section{Refine Prototype}

In this step, the feedback and the review comments are discussed during this stage and some negotiations happen with the customer based on factors like time and budget constraints and technical feasibility of actual implementation. The changes accepted are again incorporated in the new Prototype developed and the cycle repeats until customer expectations are met.

\section{Engineer Product}

In this step, the finished product will be implemented and deployed.

\section{System Architecture}

As shown in figure 3 the database will serve as the repository of data, data will be supplied by the administrator through the web application interface. The content management application system application contains the set of rules, procedures, in managing web content as well as establishing account privileges for security. It will be hosted online through a web application server. The user interface will provide for the user to interact with the system, since it is web based, the user will interact through the browser and process the request. The requested information will be processed by the content management system and the generated result will be displayed. 


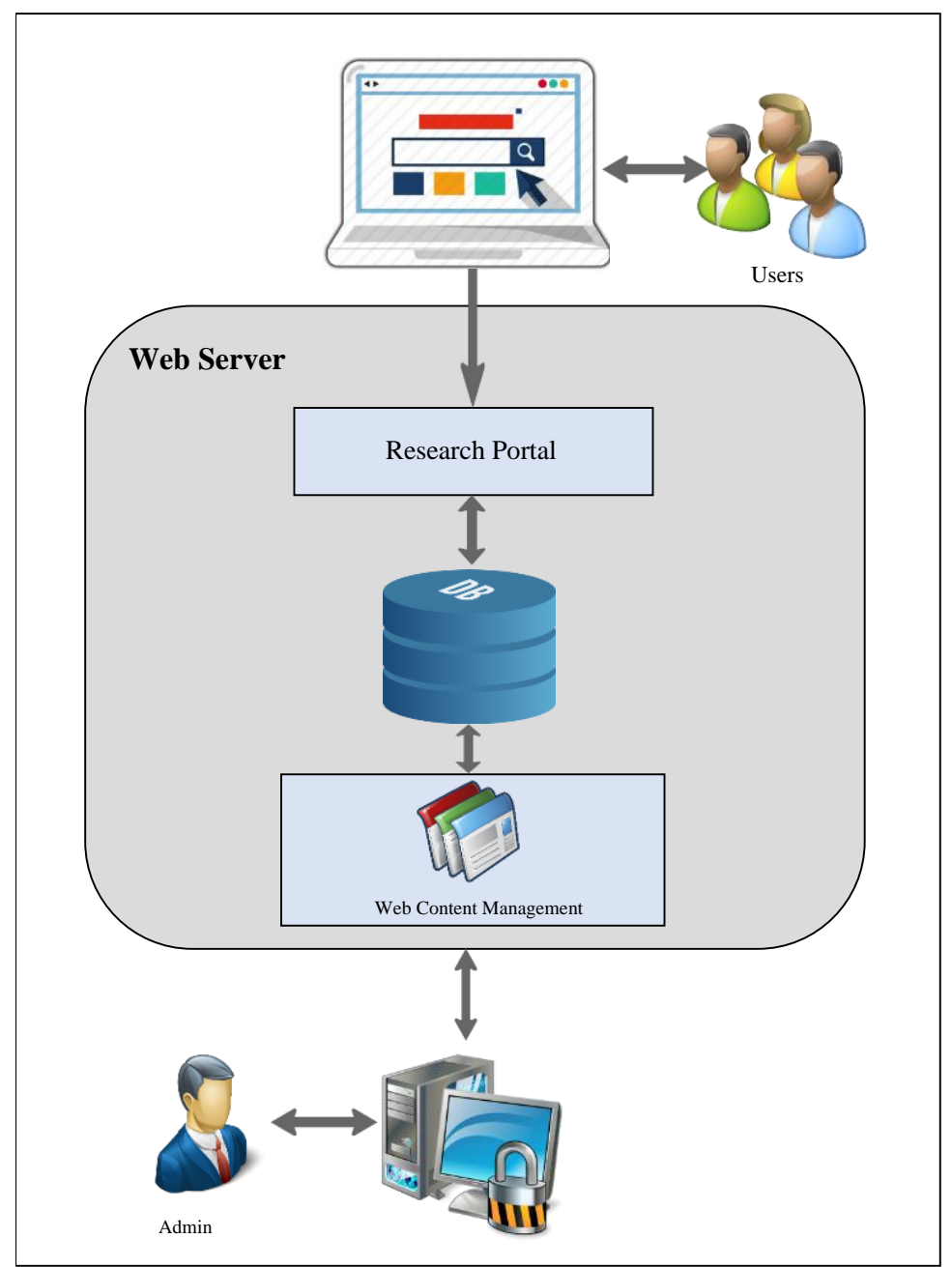

Figure 3 System Architecture

\section{Operation and Testing}

After the development, a test case was created and the researcher presented the system to the technical panel for evaluation. There are some errors that were found out during the technical presentation and series of revisions and improvements were done to correct the errors and improve the functionality.

\section{Evaluation}

The system was evaluated using the ISO 9126 standard questionnaire. The questionnaire sought to evaluate the system using the standards set by ISO 9126 otherwise known as the Software Quality Model in terms of six main characteristics of good software, namely, functionality, reliability, usability, efficiency, maintainability and portability (Pressman 2005).

The evaluators were five (5) IT Experts who are in line with web development. For the users, it was evaluated by twentyfive (25) faculty with a minimum Master's Degree Holder who were chosen randomly.

The researcher used the five (5) point Likert Scale as the basis for evaluating the system.

\section{Likert Scale Rating}

$\begin{aligned} \text { Rating } & \text { Description } \\ 5 & \text { Very Effective } \\ 4 & \text { Effective } \\ 3 & \text { Moderately Effective } \\ 2 & \text { Ineffective } \\ 1 & \text { Very Ineffective }\end{aligned}$

The result of the evaluation was tabulated using the Statistical Package for Social Sciences (SPSS) software and Mean was used to determine the result of the evaluation. 
To determine the effectiveness of the application the mean scores were categorized as follows:

Scale Verbal Interpretation

$\begin{array}{ll}4.21-5.00 & \text { Very Effective } \\ 3.41-4.20 & \text { Effective } \\ 2.61-3.40 & \text { Moderately Effective } \\ 1.81-2.61 & \text { Ineffective } \\ 1.0-1.80 & \text { Very Ineffective }\end{array}$

\section{RESULTS}

\section{Evaluation of the System using ISO 9126}

In the implementation of the system, an evaluation was conducted to test the quality standard of the system using ISO 9126 in terms of functionality, reliability, usability, efficiency, maintainability and portability. This was evaluated by panel of experts, and faculty.

The results of the evaluation of the system using the ISO 9126 are hereby presented:

Table 1 shows the result of the expert's evaluation of the system.

Table 1. Result of the Expert's Evaluation

\begin{tabular}{|c|c|c|c|}
\hline ISO 9126 Software Quality Criteria & Mean & $\begin{array}{c}\text { Std. } \\
\text { Deviation }\end{array}$ & Description \\
\hline \multicolumn{4}{|l|}{ A. Functionality } \\
\hline $\begin{array}{l}\text { 1. The system functions appropriately according to its } \\
\text { specified attribute. }\end{array}$ & 4.00 & 0 & Very Good \\
\hline $\begin{array}{l}\text { 2. The system produces accurate result and functions } \\
\text { without errors or problems. }\end{array}$ & 4.00 & 0 & Very Good \\
\hline $\begin{array}{l}\text { 3. The system adheres to related standards or } \\
\text { conventions or regulations in laws. }\end{array}$ & 3.80 & 0.447 & Very Good \\
\hline $\begin{array}{l}\text { 4. The system has the ability to prevent unauthorized } \\
\text { access to programs or data whether accidental } \\
\text { or deliberate. }\end{array}$ & 4.80 & 0.447 & Excellent \\
\hline Total & 4.15 & 0.223 & Very Good \\
\hline \multicolumn{4}{|l|}{ B. Reliability } \\
\hline $\begin{array}{l}\text { 1. The system functions for a long time without } \\
\text { crashes or service interruptions. }\end{array}$ & 3.80 & 0.447 & Very Good \\
\hline $\begin{array}{l}\text { 2. The software can manage and/or recover from } \\
\text { component or environmental failure. }\end{array}$ & 3.80 & 0.447 & Very Good \\
\hline $\begin{array}{l}\text { 3. The system can be revived and become fully } \\
\text { operational even in the event of failure. }\end{array}$ & 3.60 & 0.548 & Very Good \\
\hline Total & 3.73 & 0.480 & Very Good \\
\hline \multicolumn{4}{|l|}{ C. Usability } \\
\hline 1. The function of the system is easily understood. & 4.60 & 0.548 & Excellent \\
\hline $\begin{array}{l}\text { 2. The system is user-friendly. It does not require } \\
\text { learning effort for different type of user. }\end{array}$ & 4.80 & 0.447 & Excellent \\
\hline 3. The system is easy to operate. & 4.80 & 0.447 & Excellent \\
\hline Total & 4.73 & 0.480 & Excellent \\
\hline \multicolumn{4}{|l|}{ D. Efficiency } \\
\hline $\begin{array}{l}\text { 1. The system bears on response and processing } \\
\text { time and on throughput rates in performing its }\end{array}$ & 3.60 & 0.548 & Very Good \\
\hline
\end{tabular}




\begin{tabular}{|c|c|c|c|}
\hline \multirow{2}{*}{\multicolumn{4}{|c|}{ functions. }} \\
\hline & & & \\
\hline $\begin{array}{l}\text { 2. The system requires minimal amount of computing } \\
\text { resources }\end{array}$ & 3.80 & 0.447 & Very Good \\
\hline Total & 3.70 & 0.497 & Very Good \\
\hline \multicolumn{4}{|l|}{ E. Maintainability } \\
\hline $\begin{array}{l}\text { 1. The system has the ability to report the root cause } \\
\text { of failure. }\end{array}$ & 4.00 & 0.707 & Very Good \\
\hline 2. The system can manage to system changes. & 4.40 & 0.548 & Very Good \\
\hline $\begin{array}{l}\text { 3. The system requires less effort for modification, } \\
\text { fault removal or environmental change. }\end{array}$ & 4.00 & 0 & Very Good \\
\hline $\begin{array}{l}\text { 4. Lesser effort needed to verify or test a system } \\
\text { change. }\end{array}$ & 4.00 & 0 & Very Good \\
\hline Total & 4.10 & 0.313 & Very Good \\
\hline \multicolumn{4}{|l|}{ F. Portability } \\
\hline $\begin{array}{l}\text { 1. The system can easily adapt to changes such as } \\
\text { new specifications, operating environments or } \\
\text { upgrades in system requirements. }\end{array}$ & 4.00 & 0.707 & Very Good \\
\hline $\begin{array}{l}\text { 2. The system is easy to install. Component software } \\
\text { is also easy to install. }\end{array}$ & 3.80 & 0.447 & Very Good \\
\hline 3. The system conformed with the industry standard. & 4.20 & 0.447 & Very Good \\
\hline $\begin{array}{l}\text { 4. The system allows easy exchange of given } \\
\text { software/hardware component within specified } \\
\text { environment. }\end{array}$ & 4.00 & 0 & Very Good \\
\hline Total & 4.00 & 0.400 & Very Good \\
\hline Over-All Mean & 4.06 & 0.398 & Very Good \\
\hline
\end{tabular}

As shown in the Table 1, the expert's evaluation on the functionality was very good with mean score of 4.15 . This means that the totality of the system's function was very good. The system functioned correctly and served its purpose.

As to system's reliability, the result was very good with the mean of 3.73. This means that the system has the ability maintain its service and withstand to factors that may affect its service. It ensures that the website is always online and accessible.

As to system usability, the result showed an excellent rating with the mean score of 4.73 . This means that the system was easy to use. It had the capability to be understood, learned, used and attractive to the user, when used under specified conditions. This may imply that web application is user-friendly where in it provides ease of use in accessing the website.

As to system's efficiency, the result showed a very good evaluation rating with the mean of 3.70 . This means that the system's performance was not affected by the amount of resource utilization and could continue to deliver its function under certain conditions. This may imply that the system can cater to multiple and parallel inquiry, and for web based, it can cater to large number of traffic who are accessing the website.

As to system's maintainability, the result showed a very good evaluation rating with a mean score of 4.10 . This means that the system required less effort to maintain and the services would not be affected during the maintenance period.

As to system's portability, the result revealed very good evaluation rating with a mean score of 4.00 . This means that the system could easily adapt to changes such as new specifications, operating environments or upgrades in system requirements without affecting its operation.

The overall result of the expert's evaluation on the system based on ISO 9126 criteria was very good with the mean score of 4.06. This may mean that the system could meet the software quality characteristics set by ISO 9126 standards. This may imply that the system is of good quality and it provides quality service to its clientele.

\section{Evaluation of the Level of Effectiveness}

To determine the level of effectiveness of the system, it was presented to 25 faculty to test the system. Table 2 shows the result of the evaluation of the research portal as evaluated by the faculty. 
Table 2. Faculty Evaluation of the Research Portal

\begin{tabular}{|c|c|c|c|}
\hline \multicolumn{4}{|c|}{ Faculty } \\
\hline System Characteristics & Mean & $\begin{array}{c}\text { Std. } \\
\text { Deviation }\end{array}$ & Description \\
\hline 1. The online portal is accessible. & 4.37 & 0.701 & Very Effective \\
\hline 2. The interface is user friendly. & 4.72 & 0.451 & Very Effective \\
\hline 3. There is validation in the Registration Process & 5.00 & 0 & Very Effective \\
\hline 4. The data is secured & 5.00 & 0 & Very Effective \\
\hline $\begin{array}{l}\text { 5. The portal contains mechanism to search for research } \\
\text { outputs }\end{array}$ & 4.70 & 0.463 & Very Effective \\
\hline 6. The portal has the ability to store content. & 4.76 & 0.43 & Very Effective \\
\hline 7. The portal has the ability to manage content & 4.42 & 0.496 & Very Effective \\
\hline 8. The portal contains mechanism to grant access & 4.85 & 0.361 & Very Effective \\
\hline 9. The portal has a support for collaboration & 4.77 & 0.422 & Very Effective \\
\hline 10. The generated result is accurate & 5.00 & 0 & Very Effective \\
\hline 11. Overall function & 4.63 & 0.485 & Very Effective \\
\hline TOTAL & 4.75 & 0.346 & Very Effective \\
\hline
\end{tabular}

The overall result of the evaluation was "Very Effective" with overall mean score of 4.75 . This means that that the research portal was very effective in delivering online services.

\section{Implementation of the System}

In the development of the system, it was tested properly to ensure its proper function. It was tested at the ISAT U Miagao Campus Research Department and it can be accessed at www.sipc.edu.ph/portal.

Based on the overall evaluation of the system, data showed that it met the software quality characteristics as defined by ISO 9126 standard. In terms of its level of effectiveness, it was rated as very effective. After the evaluation, the system would be recommended for implementation to provide manage and publish the research outputs of the university.

\section{CONCLUSIONS AND RECOMMENDATIONS}

\section{Conclusions}

Based on the findings of the study, the following conclusions are drawn:

1. The overall result of the IT experts' evaluation of the ISO 9126 criteria in terms of functionality, reliability, efficiency, maintainability, and portability is very good. It implies that the proposed system meets the criteria for the software quality.

2. The result of the evaluation of the level of effectives of the research portal is very effective which means that the performance of the system in terms of effectiveness is very effective to the users.

3. Based on the result of the evaluation, the study achieved its objectives.

\section{Recommendations}

Based on the foregoing findings and conclusions, the following courses of action are hereby recommended:

1. To maintain the performance of the system and ensure its proper function, proper monitoring must be conducted to check that the online portal is always accessible.

2. Since the system meets the criteria for software quality characteristics, the researcher recommends the full implementation of the research portal.

3. It is also recommended to present the portal to research agencies and CHED to seek recognition as online research publication.

4. It is further recommended for the conduct of similar and related studies in the future for further improvement of the system. 


\section{REFERENCES}

1. Englert, B, (2003). Portals Trends In Higher Education. Educause Southwest Regional Conference 2003. Retrieved from http://www.educause.edu/asp/doclib/abstract.asp?ID=SWR0304

2. Hongkong Polytechnic University Research Office Portal. Retrieved from https://www40.polyu.edu.hk/rostudportal

3. ISO 9126 Software Quality Characteristics. Retrieved from: http://www.sqa.net/iso9126.html

4. Natural Sciences and Engineering Research Council of Canada Research Portal http://www.nserccrsng.gc.ca/ResearchPortal-PortailDeRecherche/Index_eng.asp

5. Pressman, R.S., (2005).Software Engineering a Practitioners Approach, 6th Edition. New Jersey: Prentice Hall, Inc.

6. Richard N. Katz and Associates, 2002. Web Portals and Higher Education Technologies to Make IT Personal. Retrieved from https://net.educause.edu/ir/library/pdf/pub5006g.pdf

7. Socio Economic Research Portal for the Philippines. Retrieved from http://serp-p.pids.gov.ph/home/index.html

8. The Getty Research Portal. Retrieved from http://portal.getty.edu/portal/landing

9. University of the Philippines Los Baños Portal. Retrieved from http://uplb.edu.ph/index.php/research 